\title{
PENGARUH TERAPI DZIKIR TERHADAP PENURUNAN TINGKAT KECEMASAN PADA PASIEN PRE OPERASI BESAR DI RUMAH SAKIT CIREMAI CIREBON TAHUN 2015
}

\author{
Agus Sutarna*Riana Budi Arti**
}

\begin{abstract}
ABSTRAK
Pembedahan, baik elektif maupun kedaruratan adalah peristiwa kompleks yang menegangkan. Cemas merupakan suatu keadaan emosi tanpa suatu objek yang spesifik dan pengalaman subjektif dari individu serta dan tidak dapat diobservasi dan dilihat secara langsung. Sebelum dilakukan operasi terdapat masalah kecemasan yang merupakan reaksi emosional pasien yang sering muncul. Terapi medis saja tanpa disertai dzikir tidaklah lengkap. Untuk menurunkan tingkat kecemasan pada pasien pre operasi besar dengan cara terapi dzikir. Tujuan penelitian ini adalah untuk mengetahui pengaruh terapi dzikir terhadap penurunan tingkat kecemasan pada pasien pre operasi besar di Rumah Sakit Ciremai Cirebon tahun 2015.

Penelitian ini menggunakan jenis penelitian Quasi Experiment dengan rancangan one group pretest - posttest. Populasi dalam penelitian ini yaitu 103 pasien. Sampel dalam penelitian ini yaitu 32 subjek dengan menggunakan teknik purposive sampling. Pengukuran tingkat kecemasan menggunakan skala kecemasan Hamilton Anxiety Rating Scale (HARS). Cara pengambilan data menggunakan Kuesioner. Teknik analisa data menggunakan uji wilcoxon. Hasil penelitian nilai $\rho$ value $0,000 \quad(\rho<0,05)$. Hal ini berarti $\mathrm{H}_{0}$ gagal ditolak, yang artinya bahwa terapi dizikir dapat menurunkan tingkat kecemasan pada pasien pre operasi besar di Rumah Sakit Ciremai Kota Cirebon Tahun 2015.

Penelitian ini diharapkan sebagai sumber informasi dalam rangka meningkatkan upaya pelayanan kesehatan dengan melakukan pelatihan terapi dzikir, khususnya pada pasien pre operasi besar yang mengalami kecemasan.
\end{abstract}

Kata Kunci : Pre Operasi, Kecemasan, Terapi Dzikir

\begin{abstract}
Surgery, both elective and emergency is complex stressful events. Anxiety is an emotional state without a specific object and the subjective experience of the individual as well and can not be observed and seen directly. Before the operation there is a problem that concerns the patient's emotional reactions that often arise. Medical therapy alone without dzikir is not complete. To reduce the level of anxiety in patients with preoperative great by the way dhikr therapy. The purpose of this study was to determine the effect of the decrease in the level of dhikr therapy in patients with preoperative anxiety large in Ciremai hospital cirebon 2015.

This study uses a type of research design Quasi Experiment with one group pretest - posttest. Population in this research is 103 patients. The sample in this study is 32 subjects using purposive sampling technique. Measuring the level of anxiety using the Hamilton anxiety scale Anxiety Rating Scale (HARS). How to collect data by questionnaire. Data analysis techniques using Wilcoxon test. The results of the research value of $\rho$ value of $0.000(\rho<0.05)$. which means $H_{0}=$ ditolak, dhikr therapy can reduce the level of anxiety in patients with mayor preoperativei in Cirebon City Hospital Ciremai Year 2015.

This research is expected as resources in order to improve health care efforts by conducting training dhikr therapy, especially in patients who undergo major surgery pre anxiety.

Keywords : Pre Operations, anxiety, therapy dzikir
\end{abstract}

\footnotetext{
*Staf Pengajar PSIK STIKes Cirebon

**Alumni PSIK STIKes Cirebon
} 


\section{PENDAHULUAN}

Pembedahan atau tindakan operatif, baik elektif maupun kedaruratan adalah peristiwa kompleks yang menegangkan. Segala bentuk pembedahan tersebut selalu didahului dengan suatu reaksi emosional tertentu oleh pasien, apakah reaksi itu jelas atau tersembunyi, normal atau abnormal. ${ }^{1}$

Pasien yang akan menjalani operasi/pembedahan dapat mengalami kecemasan yang merupakan reaksi umum terhadap kondisi yang dirasakan sebagai suatu ancaman terhadap perannya dalam hidup, integritas tubuh,atau bahkan kehidupannya itu sendiri. Pasien yang mengalami ansietas akan merasa tidak enak dan takut, dan mengalami rasa ngeri yang tidak jelas. Perasaan tidak berdaya dapat terjadi, disertai rasa terasing dan tidak aman. Intensitas perasaan ini dapat ringan atau cukup berat sampai menyebabkan kepanikan, dan intensitasnya dapat meningkat atau menghilang tergantung pada kemampuan koping individu dan sumber-sumber yang ada. ${ }^{1}$

Kecemasan dapat ditimbulkan dari peristiwa sehari-hari yang dapat dialami manusia dan dapat juga dialami oleh siapapun. Cemas merupakan suatu keadaan emosi tanpa suatu objek yang spesifik dan pengalaman subjektif dari individu serta dan tidak dapat diobservasi dan dilihat secara langsung. Cemas berbeda dengan rasa takut, karakteristik rasa takut adalah hanya suatu objek sumber yang spesifik dan dapat diidentifikasi serta dapat dijelaskan oleh individu sedangkan kecemasan diartikan sebagai suatu kebingungan, kekhawatiran pada sesuatu yang akan terjadi dengan penyebab atau objek yang tidak jelas dan dihubungkan dengan perasaan tidak menentu dan tidak berdaya. ${ }^{2}$ Dengan demikian kecemasan adalah kekhawatiran yang dialami seseorang yang akan menjalani menghadapi operasi/pembedahan.

Berdasarkan data dari Rumah Sakit Umum Pusat (RSUP) Fatmawati tahun 2012, di dapatkan bahwa 10\% dari klien yang akan menjalani pembedahan, terjadi penundaan proses operasi/pembatalan proses operasi. Diantaranya 5\% kasus pembatalan/penundaan proses operasi disebabkan peningkatan tekanan darah, $2 \%$ kasus disebabkan klien haid,dan 3\% disebabkan klien ketakutan dan keluarga klien menolak untuk dilakukannya proses operasi. Penelitian yang dilakukan oleh Ferlina Indra S pada tahun 2012 tentang tingkat kecemasan pre operasi di Rumah Sakit Umum Daerah (RSUD) Sragen, bahwa dari 40 orang responden yang menjalani operasi dalam tingkat kecemasan berat sebanyak 7 orang $(17,5 \%), 16$ orang $(40 \%)$ yang memiliki tingkat kecemasan sedang, 15 orang $(37,5 \%)$ ringan dan 2 orang $(5 \%)$ responden yang tidak merasa cemas. $^{3}$

Maka dari itu, dalam menghadapi ketakutan dan kecemasan pasien pre operasi, terdapat penatalaksanaan secara farmakologi dan nonfarmakologi. Penatalaksanaan farmakologi yaitu menggunakan obat untuk anti kecemasan terutama benzodiazepine. ${ }^{4}$. Sedangkan penatalaksanaan non farmakologis dengan cara distraksi dan relaksasi. Relaksasi adalah teknik mengatasi kekhawatiran atau kecemasan melalui pengendoran otot-otot dan saraf itu terjadi bersumber pada objek-objek tertentu. Salah satu relaksasi yang efektif untuk menurunkan kecemasan adalah dengan cara memberikan dukungan spiritual (membacakan doa atau dzikir sesuai agama dan keyakinannya). ${ }^{4}$

Dzikir adalah mengucapkan kata-kata pujian yang mengingat kebesaran Allah SWT. ${ }^{5}$. Terapi dzikir dapat menurunkan hormon-hormon stressor, mengaktifkan hormon endorfin alami, meningkatkan perasaan rileks, dan mengalihkan perhatian dari rasa takut, cemas dan tegang, memperbaiki sistem kimia tubuh sehingga menurunkan tekanan darah serta memperlambat pernafasan, detak jantung, denyut nadi, dan aktivitas gelombang otak. Laju pernafasan yang lebih dalam atau lebih lambat tersebut sangat baik menimbulkan ketenangan, kendali emosi, pemikiran yang lebih dalam dan metabolisme yang lebih baik. ${ }^{4}$

Penelitian yang dilakukan oleh Mardiyono dkk pada tahun 2007 yang meneliti tentang efek dzikir terhadap kecemasan pasien yang akan dioperasi juga menunjukkan nilai yang signifikan $(\mathrm{p}=<0.05)$. Penelitian tersebut $(\mathrm{n}=70)$ menggunakan kata kata Subhannallah selama 25 menit sebelum dilakukan operasi dimana seluruh pasien menunjukkan hasil tidak cemas. ${ }^{6}$ Penelitian yang dilakukan Sutrisno (2006) dengan judul Pengaruh Bimbingan Doa dan Dzikir Terhadap Kecemasan Pasien Pre Operasi. Penelitian resebut dilakukan di RSUD Swadana Pare 
Kediri. Subyek penelitian adalah pasien pre operasi di RSUD Swadana Pare Kediri, yang masing-masing diambil sebanyak 20 orang untuk kelompok eksperimen dan 20 orang untuk kelompok kontrol. Hasil penelitian tersebut membuktikan ada perbedaan yang signifikan pada kecemasan pasien pre operasi antara pasien yang diberi bimbingan doa dan dzikir dengan yang tidak $(\mathrm{t}=-3,344 \text { dan } \mathrm{p}=0,002)^{7}$

Berdasarkan hasil studi pendahuluan di Rumah Sakit Ciremai Kota Cirebon, pada tiga bulan terakhir yaitu bulan November 2014 hingga bulan Januari 2015 terdapat pasien pre operasi besar sebanyak 310 pasien.

Berdasarkan fenomena diatas maka peneliti tertarik melakukan penelitian dengan judul "pengaruh terapi dzikir terhadap penurunan tingkat kecemasan pada pasien pre operasi besar di Rumah Sakit Ciremai Cirebon tahun 2015”.

\section{METODE PENELITIAN}

Penelitian ini menggunakan jenis penelitian Quasi Experiment yaitu eksperimen ini belum atau tidak memiliki ciri-ciri rancangan eksperimen sebenarnya, karena variabel-variabel yang seharusnya dikontrol atau dimanipulasi tidak dapat atau sulit dilakukan. ${ }^{8}$ Penelitian ini dengan pendekatan one group pretest - posttest yaitu mengungkapkan hubungan sebab akibat dengan cara melibatkan satu kelompok subjek. Kelompok subjek diobservasi sebelum dilakukan intervensi, kemudian diobservasi lagi setelah intervensi. ${ }^{9}$

Pada Penelitian ini, sebelum dilakukan terapi dzikir, tingkat kecemasan (pretest) pasien diukur 1 jam sebelum operasi, kemudian dilakukan terapi dzikir (intervensi) oleh Peneliti selama \pm 10 menit. Setelah itu diukur kembali tingkat kecemasan (post-test) pasien tersebut. Populasi dalam penelitian ini adalah pasien pre operasi besar yang ada di Rumah Sakit Ciremai Cirebon periode bulan November-Januari 2015 sebanyak 310 dengan rata-rata pasien dalam satu bulan yaitu 103 orang. Teknik pengambilan sampel dalam penelitian ini adalah teknik Purposive Sampling yang merupakan cara pengambilan sampel berdasarkan pertimbangan tertentu yang telah dibuat oleh peneliti ${ }^{8}$ yang meliputi subjek yang memenuhi kriteria. Kriteria sampel dalam penelitian ini adalah Pasien yang beragama Islam, pasien yang sadar dengan GCS 15, pasien bersedia menjadi responden. Karena keterbatasan waktu dan kasus dalam penelitian ini, maka peneliti hanya mengambil sampel minimal yaitu sebanyak 32 responden. Alat ukur atau instrument dalam penelitian ini untuk variabel dependen yaitu skala kecemasan (skala HARS). Analisa data menggunakan uji Wilcoxon Matched Pairs dengan rumus sebagai berikut :

$$
Z=\frac{T-\frac{N(N+1)}{4}}{\sqrt{\frac{N(N+1)(2 N+1)}{24}}}
$$

Uji Wilcoxon Matched Pairs adalah prosedur non-parametik yang digunakan dalam pengujian hipotesis yang menempatkan desain dengan dua sempel berpasangan. Untuk pengambilan keputusannya adalah Ho ditolak jika : $\mathrm{p}$-value $\leq 0,05$ dan Ho gagal ditolak jika $\mathrm{p}$-value $>0,05$.

\section{HASIL PENELITIAN}

Hasil penelitian yang dilakukan di uraikan pada table dibawah ini:

Berdasarkan hasil pengukuran tingkat kecemasan dengan menggunakan skala HARS (skor <14-56) didapatkan hasil sebagai berikut: 
Tabel 1. Distribusi Frekuensi Tingkat Kecemasan Pada Pasien Pre Operasi Besar Sebelum Dilakukan Terapi Dzikir

\begin{tabular}{lcc}
\hline \multicolumn{1}{c}{ Tingkat kecemasan } & Frekuensi & Presentase $(\%)$ \\
\hline Tidak ada kecemasan & 0 & 0 \\
Kecemasan ringan & 23 & 71,9 \\
Kecemasan sedang & 8 & 25 \\
Kecemasan berat & 1 & 3,1 \\
Kecemasan berat sekali & 0 & 0 \\
\hline Jumlah & 32 & 100 \\
\hline
\end{tabular}

Hasil penelitian didapatkan gambaran persepsi pasien tentang tingkat kecemasan sebelum dilakukan terapi dzikir adalah $71.9 \%$ untuk kecemasan ringan, $25.0 \%$ untuk kecemasan sedang dan $3,1 \%$ untuk kecemasan berat.

Tabel 2. Distribusi Frekuensi Tingkat Kecemasan Pada Pasien Pre Operasi Besar sesudah dilakukan Terapi Dzikir

\begin{tabular}{lcc}
\hline \multicolumn{1}{c}{ Tingkat kecemasan } & Frekuensi & Presentase (\%) \\
\hline Tidak ada kecemasan & 20 & 62,5 \\
Kecemasan ringan & 11 & 34,4 \\
Kecemasan sedang & 1 & 3,1 \\
Kecemasan berat & 0 & 0 \\
Kecemasan berat sekali & 0 & 0 \\
\hline Jumlah & 32 & 100 \\
\hline
\end{tabular}

Hasil penelitian didapatkan gambaran persepsi pasien tentang tingkat kecemasan sesudah dilakukan terapi dzikir adalah 62,5\% untuk tidak ada kecemasan, 34,4\% untuk kecemasan ringan dan $3,1 \%$ untuk kecemasan sedang.

Tabel 3. Distribusi Frekuensi Perbedaan Terapi Dzikir terhadap Penurunan Tingkat Kecemasan Pada Pasien Pre Operasi

\begin{tabular}{rccccc}
\hline No & Variabel & Mean & SD & $\boldsymbol{P}$ & $\boldsymbol{N}$ \\
\hline 1 & Pretest & 18,69 & 3,364 & 0,000 & 32 \\
2 & Posttest & 13,34 & 3,239 & & 32 \\
\hline
\end{tabular}

Tabel 3 dapat diketahui bahwa tingkat kecemasan pada pasien pre operasi sebelum diberikan terapi dzikir dengan rata-rata 18,69 dan standar deviasi 3,364. Sementara tingkat kecemasan setelah diberikan terapi dzikir dengan rata-rata 13,34 dan standar deviasi 3,239.

Berdasarkan hasil uji statistik dengan uji hipotesis Wilcoxon dengan derajat kemaknaan 95\%, diperoleh $\rho$ value $0,000(\rho<0,05)$ sehingga terdapat perbedaan antara tingkat kecemasan sebelum dan sesudah dilakukan terapi dzikir pada Pasien Pre Operasi Besar hal ini berarti $\mathrm{H}_{0}$ gagal ditolak, yang artinya bahwa terapi dizikir dapat menurunkan tingkat kecemasan pada pasien pre operasi besar di Rumah Sakit Ciremai Kota Cirebon Tahun 2015.

\section{PEMBAHASAN}

\section{Tingkat kecemasan sebelum dilakukan terapi dzikir pada pasien pre operasi besar}

Sebelum dilakukan terapi dzikir, peneliti melakukan pengukuran tingkat kecemasan dengan menggunakan skala HARS. Hasil penelitian didapatkan dari 32 responden sebagaian besar responden merasakan kecemasan ringan sebanyak 23 responden $(71,9 \%)$, kecemasan sedang sebanyak 8 responden $(25.0 \%)$ dan untuk kecemasan berat sebanyak 1 responden $(3,1 \%)$. 
Menurut asumsi peneliti, sebagian besar responden mengalami kecemasan ringan yang disebabkan karena faktor pencetus ketakutan akan pembiusan, takut akan rasa nyeri dan lingkungan yang baru.

Faktor-faktor yang dapat menjadi pencetus terjadinya kecemasan antara lain ancaman terhadap integritas seseorang yang meliputi ketidakmampuan fisiologis atau menurunnya kemampuan untuk melakukan aktivitas hidup sehari-hari dan ancaman terhadap sistem diri seseorang dapat membahayakan identitas harga diri dan fungsi sosial yang terintegrasi dari seseorang. Pada pasien yang akan menjalani operasi faktor pencetus kecemasannya adalah faktor yang dialami individu baik bersifat internal maupun eksternal. Faktor internalnya adalah adanya ketakutan akan pembiusan, kecacatan, kematian, takut akan rasa nyeri, takut kehilangan pekerjaan, menjadi tanggungan keluarga. Sedangkan faktor eksternalnya adalah lingkungan yang baru, peralatan operasi atau pembiusan yang asing serta petugas kesehatannya. ${ }^{10}$

Maka dari itu, dalam menghadapi ketakutan dan kecemasan pasien pre operasi, terdapat penatalaksanaan secara farmakologi dan nonfarmakologi. Penatalaksanaan farmakologi yaitu menggunakan obat untuk anti kecemasan terutama benzodiazepine. ${ }^{4}$ Sedangkan penatalaksanaan non farmakologis dengan cara distraksi dan relaksasi. Relaksasi adalah teknik mengatasi kekhawatiran atau kecemasan melalui pengendoran otot-otot dan saraf itu terjadi bersumber pada objek-objek tertentu. Salah satu relaksasi yang efektif untuk menurunkan kecemasan adalah dengan cara memberikan dukungan spiritual (membacakan doa atau dzikir sesuai agama dan keyakinannya). ${ }^{4}$ Dengan terapi dzikir yang baik dan benar akan menimbulkan ketentraman hati, terbebas dari gundah, cemas, dan gelisah. ${ }^{11}$

\section{Tingkat Kecemasan Sesudah Dilakukan Terapi Dzikir pada Pasien Pre Operasi Besar}

Berdasarkan hasil pengukuran tingkat kecemasan setelah dilakukan terapi dzikir selama \pm 10 menit satu jam sebelum operasi besar didapatkan dari 32 responden sebagian besar merasakan tidak ada kecemasan sebanyak 20 responden $(62,5 \%)$, kecemasan ringan sebanyak 11 responden $(34,4 \%)$ dan untuk kecemasan sedang sebanyak 1 responden $3,1 \%$. Hal ini berarti terjadi penurunan tingkat kecemasan setelah dilakukan terapi dzikir selama \pm 10 menit satu jam sebelum operasi.

Dari hasil penelitian menunjukan, bahwa dengan melakukan terapi dzikir selama \pm 10 menit satu jam sebelum operasi dapat terjadi penurunan tingkat kecemasan pada pasien pre opesi besar. Hal ini membuktikan bahwa terapi dzikir efektif dapat menurunkan tingkat kecemasan pada pasien pre operasi besar.

Terapi dzikir dapat menimbulkan perasaan tenang dan tenteram dalam jiwa, merupakan terapi bagi kegelisahan manusia ketika dia mendapatkan masalah, merasa dirinya lemah tidak mempunyai penyangga dan penolong menghadapi berbagai tekanan dan bahaya kehidupan. ${ }^{12}$ Dengan berdzikir atau mengingat Allah akan memberikan kita perasaan aman dan tentram, ini artinya kita akan terbebas dari gundah, cemas, dan gelisah.

Untuk menurunkan tingkat kecemasan dengan cara penanganan nonfarmakologi yaitu dengan relaksasi. Salah satu relaksasi yang efektif untuk menurunkan kecemasan adalah dengan cara terapi dzikir. Terapi dzikir merupakan mengucapkan kata-kata pujian yang mengingat kebesaran Allah SWT.

\section{Perbedaan Tingkat Kecemasan Sebelum dan Sesudah Dilakukan Terapi Dzikir pada Pasien Pre Operasi Besar}

Berdasarkan hasil uji statistik dengan uji hipotesis Wilcoxon dengan derajat kemaknaan $95 \%$, diperoleh $\rho$ value $0,000 \quad(\rho<0,05)$ sehingga terdapat perbedaan yang signifikasi antara tingkat kecemasan sebelum dan sesudah dilakukan terapi dzikir pada Pasien Pre Operasi Besar. Hal ini berarti $\mathrm{H}_{0}$ ditolak, yang artinya bahwa terapi dizikir dapat menurunkan tingkat kecemasan pada pasien pre operasi besar di Rumah Sakit Ciremai Kota Cirebon Tahun 2015.

Dari hasil penelitian menunjukan, bahwa sebelum dan sesudah dilakukan terapi dzikir selama \pm 10 menit satu jam sebelum operasi terdapat perbedaan yang signifikan terhadap tingkat 
kecemasan pada pasien pre opesi besar. Hal ini membuktikan bahwa terapi dzikir efektif dapat menurunkan tingkat kecemasan pada pasien pre operasi besar.

Hal ini sesuai dengan Penelitian yang dilakukan Sutrisno (2006) dengan judul Pengaruh Bimbingan Doa dan Dzikir Terhadap Kecemasan Pasien Pre Operasi. Penelitian tersebut dilakukan di RSUD Swadana Pare Kediri. Subyek penelitian adalah pasien pre operasi di RSUD Swadana Pare Kediri, yang masing-masing diambil sebanyak 20 orang untuk kelompok eksperimen dan 20 orang untuk kelompok kontrol. Hasil penelitian tersebut membuktikan ada perbedaan yang signifikan pada kecemasan pasien pre operasi antara pasien yang diberi bimbingan doa dan dzikir dengan yang tidak $(\mathrm{t}=-3,344$ dan $\mathrm{p}=0,002)$.

Kebiasaan melakukan dzikir dengan baik dan benar akan menimbulkan ketentraman hati, terbebas dari gundah, cemas, dan gelisah. Berdzikir kepada Allah adalah suatu ibadah yang membawa ketenangan dan penyembuhan jiwa. Hadist riwayat Baihaqi : Menyebut-nyebut Allah adalah suatu penyembuhan dan menyebut-nyebut tentang manusia adalah penyakit (artinya penyakit akhlak). ${ }^{10}$

Terapi dzikir dapat menurunkan hormon-hormon stressor, mengaktifkan hormon endorfin alami, meningkatkan perasaan rileks, dan mengalihkan perhatian dari rasa takut, cemas dan tegang, memperbaiki sistem kimia tubuh sehingga menurunkan tekanan darah serta memperlambat pernafasan, detak jantung, denyut nadi, dan aktivitas gelombang otak. Laju pernafasan yang lebih dalam atau lebih lambat tersebut sangat baik menimbulkan ketenangan, kendali emosi, pemikiran yang lebih dalam dan metabolisme yang lebih baik.

\section{SIMPULAN}

1. Tingkat kecemasan pada pasien pre operasi besar sebelum dilakukan terapi dzikir sebagian besar adalah kecemasan ringan $(71.9 \%)$.

2. Tingkat kecemasan pada pasien pre operasi besar sesudah dilakukan terapi dzikir sebagian besar adalah tidak ada kecemasan $62,5 \%$

3. Terdapat perbedaan yang signifikasi antara terapi dizikir dengan tingkat kecemasan pada pasien pre operasi besar di Rumah Sakit Ciremai Kota Cirebon Tahun 2015 dengan nilai $p=0,000$. Hal ini berarti $\mathrm{H}_{0}$ gagal ditolak, yang artinya bahwa terapi dizikir dapat menurunkan tingkat kecemasan pada pasien pre operasi besar di Rumah Sakit Ciremai Kota Cirebon Tahun 2015

\section{SARAN}

1. Bagi Institusi Pendidikan STIKes Cirebon

Diharapkan mampu merancang sesuatu model pelatihan tentang terapi dzikir baik teori maupun praktek sebagai cara untuk menurunkan tingkat kecemasan pasien pre operasi ini dapat diterapkan oleh mahasiswa keperawatan.

2. Bagi Ilmu Keperawatan

Penelitian ini diharapkan menjadi bahan kajian atau informasi tambahan untuk penelitianpenelitian lebih lanjut yang terkait dengan terapi dzikir dan tingkat kecemasan pasien pre operasi besar.

3. Bagi Peneliti Lain

Penelitian ini diharapkan menjadikan acuan proses belajar dalam menerapkan ilmu mengenai terapi dzikir agar penelitian selanjutnya akan lebih baik.

4. Bagi Rumah Sakit

Diharapkan selain terapi farmakologi juga dapat menerapkan terapi komplementer yaitu terapi dzikir dalam penanganan untuk menurunkan kecemasan pada pasien pre operasi besar.

5. Praktek Keperawatan

Penelitian ini diharapkan sebagai sumber informasi dalam rangka meningkatkan upaya pelayanan kesehatan dengan melakukan pelatihan terapi dzikir, khususnya pada pasien pre operasi besar yang mengalami kecemasan. 
6. Bagi responden

Dapat memberikan pengetahuan tindakan alternatif yaitu terapi dzikir dalam membantu menurunkan kecemasan pasien pada pasien pre operasi besar.

\section{DAFTAR PUSTAKA}

1. Smeltzer, Suzanne C. dan Brenda G. Bare. Buku Ajar Keperawatan Medikal Bedah, Brunner \& Suddarth, Edisi 8. Jakarta: Penerbit EGC; 2002

2. Suliswati. Konsep Dasar Keperawatan Kesehatan Jiwa. Jakarta: EGC; 2005

3. Ayuni Chandra Venny. Hubungan Dukungan Keluarga Dengan Tingkat Kecemasan Pasien Pre Operasi Di Ruang Bedah Rsud Padang Panjang Tahun 2014.

4. Isaacs, A. Mental Health and Psychiatric Nursing. Dean Praty Rahayuningsih (penerjemah). Edisi 3. Jakarta: EGC; 2005

5. Suhaimie. Muhammad Yasin. Dzikir dan doa. Malang: Universitas Muhammadiyah Malang; 2005

6. Mardiyono, Anggraini, M., \& Dyah Sulistyowati. Pengaruh terapi Zikir terhadap penurunan kecemasan pasien prabedah mayor. Unpublished Research, Lecturer National Grand, The Ministry of Education, Indonesia. Purwokerto: Soedirman University; 2007

7. Sutrisno, J. Pengaruh Bimbingan Doa dan Dzikir Terhadap Kecemasan Pasien Pre Operasi di RSUD Swadana Pare Kediri. Laporan Hasil Penelitian Mahasiswa Fakultas Psikologi Universitas Darul, Ulum Jombang: 2011

8. Notoatmodjo Soekidjo. Metodologi Penelitian Kesehatan. Jakarta: Rineka Cipta; 2010

9. Nursalam. Konsep dan Penerapan Metodologi Penelitian Ilmu Keperawatan. Jakarta: Salemba Medika.; 2003

10. Alfandi Haryanto. Munir Syamsul. Energi dzikir menentramkan jiwa membangkitkan optimisme. Wonosobo: Amzah; 2008

11. Primadona. Pengaruh Dzikir (Membaca Al-Quran) Terhadap Perubahan Kadar Hormon T4 (Tetraiodototironin) Pada Qori Di Lingkungan IPTIK Jakarta. FKIK UIN. Jakarta; 2010

12. Ahmad Husain Ali Salim. Terapi Al-Quran untuk penyakit fisik dan psikis manusia. Jakarta: Asta Buana Sejahtera; 2006 